\title{
LEGAL REGULATIONS AND POLICY BARRIERS TO DEVELOPMENT OF RENEWABLE ENERGY SOURCES IN SOUTH AFRICA
}

\author{
Siphesihle Nene ${ }^{1}$, Henrietta Nagy ${ }^{2}$ \\ ${ }^{1}$ Hungarian University of Agriculture and Life Sciences, Hungary; \\ ${ }^{2}$ Kodolanyi Janos University, Hungary \\ nenesphe14@gmail.com,nagy.henrietta@gtk.szie.hu
}

\begin{abstract}
The current global warming crisis and energy security have revived the need for renewable energy as the best option to sustain future energy needs. However, despite having abundant natural resources, Africa is facing challenges in improving access to energy. This has been identified as the biggest stumbling block to economic development in the region. Using South Africa as a case study, this paper reviews the regulatory and policy barriers to renewable energy in the country in relation to global growth. Therefore, our paper aims to provide an overview on the background of the sector, as a theoretical basis for further research. In 2014, South Africa was in the top 10 for global investments in renewable energy and this was a step in the right direction towards encouraging energy efficiency. While there are numerous initiatives responsible for promoting energy access in South Africa; gradual progress has been achieved through energy and environmental law regulations. Law is an important social, regulatory, and economic tool that can be applied to influence and manage development. However, in South Africa environmental and energy law and policy have not adequately addressed the barriers to harness renewable energy technologies. Consequently, conventional energy resources like fossil fuels have resulted in short-term economic growth and long-term negative environmental impacts. South Africa will continue to be locked in fossil fuel energy supply systems unless they address the institutional fragmentation that is a barrier to renewable energy development. This paper concludes that legal and policy barriers should be prioritised above socio-economic and political challenges to renewable energy, as they will drive progress towards creating an enabling a regulatory environment.
\end{abstract}

Keywords: renewable energy, energy policy, legislation, development potentials, South Africa.

\section{Introduction}

There is an increasing need to give attention to energy regulations because of the significant impact they have on the economy, security, environment, and society [1]. The global trend towards reforming energy policy is explicitly shaping renewable energy development, which is apparent in the vigorous promotion of renewable energy and indirectly effecting incentives and barriers for renewable energy [2]. South Africa's renewable energy journey is in its early development years, but it is growing [3]. There are varying opinions and discussions about the physical renewable energy potential in South Africa. According to the Department of Energy in South Africa, the country has an annual 24-hour global solar radiation of about $220 \mathrm{~W} \cdot \mathrm{m}^{-2}$. In comparison it is higher than the average recorded for Europe and the United Kingdom $\left(100 \mathrm{~W} \cdot \mathrm{m}^{-2}\right)$ and parts of the USA $\left(150 \mathrm{~W} \cdot \mathrm{m}^{-2}\right)$. In addition, the $3000 \mathrm{~km}$ coastline in the South Africa offers opportunity for wind power. The estimated total wind power potential of South Africa is $67000 \mathrm{GW}$. The vast areas of flat terrain coupled with high irradiation and the large coastline support vast potential for renewable energy development [4]. In 2019, the South African energy mix consisted of renewable gas (7\%), coal (81\%), hydro (3\%), pumped storage (5\%) and nuclear (4\%). Evidently, coal constitutes approximately $80 \%$ of South Africa's energy needs, largely because South Africa is the $7^{\text {th }}$ largest producer of coal and $5^{\text {th }}$ largest coal exporter in the world. The over reliance on coal has resulted in a high level of environmental degradation [5].

The generation of electricity is the primary responsibility of the government under the state-owned power and utility company - Eskom. Eskom is solely responsible for the transmission, while distribution to the end users is achieved with the assistance of 137 local municipalities(2). At the same time, Eskom has had challenges providing stable electricity in the last decade, the energy availability factor decreased from $67.75 \%$ in 2017 to $65 \%$ in 2020 . This means that on average $35 \%$ of Eskom's power plants are inactive regularly due to faults or maintenance. This has been the main reason for the national energy crisis that saw the country experiencing rolling power cuts since 2008 . The power cuts are scheduled to last for the next 5 years [6].

The current state of South Africa's renewable energy legal regulations and policy framework raise concerns. These legal frameworks are a collection of a variety of legislation and policy documents, covering a broad range of topics that involve different sectors. One can agree with the view of Kotze (2006) that fragmentation within governance leads to inadequate and ineffective service delivery [7]. 
The basis of this paper supports this view and aims to address the evident fragmentation in governance that hinders energy efficiency in South Africa. Furthermore, the legal frameworks regulating these sectors are in most cases not aligned - a situation which contributes directly to exacerbating the existence and effects of legal and institutional fragmentation [8]. For instance, along different stages of generating and distributing renewable energy, water, agriculture, forestry, and transport are linked to the process [3]. However, the legal frameworks regulating these sectors are not well coordinated, which results in deep legal and institutional fragmentation. Murombo (2016) states that "lack of coordination and synchronisation of the legislation, institutions and sectors that should be intertwined" characterises the deep fragmentation in renewable energy regulations in South Africa [7]. This study supports this view and hypothesises that addressing the fragmentation prevalent in regulation efforts pertaining to renewable energy in South Africa is crucial to promoting a sustainable energy future. This hypothesis highlights the inherent interrelationship between governance and renewable energy regulation in encouraging sustainable energy generation.

In view of the above factors about the energy landscape of South Africa, this paper addresses the legal and policy barriers in renewable energy development within the context of the country's multifaceted electricity system and policy initiatives. This paper concludes with recommendations and strategies to improve existing renewable energy regulations and policies to enhance renewable energy generation.

\section{Materials and methods}

The methodology that was followed for this article was qualitative in nature. The study involved desk-top research. First, South Africa was selected as a target country based on pre-determined criteria. The country has been facing periodic power cuts since 2008 as a result of delayed renewable energy deployment and ageing coal power stations. The country has multiple renewable energy resources but fails to meet its own electricity demand. Next, a general search was conducted using various search engines to review literature to identify existing renewable energy legislations and policy. Then, an analysis of the legislations and policies was conducted for the selected country to identify strengths and weaknesses/shortcomings. The objective of performing this analysis is an effort towards aiding discussions on how to further develop the existing South African approach to renewable energy regulation. There is a growing need to develop a better integrated approach towards renewable energy regulations, especially when you consider how the renewable energy regulations in the country are defined by legal and institutional fragmentation and that fragmentation becomes a barrier towards achieving sustainable development. Using this approach, granted us the opportunity to make suitable recommendations to improve renewable energy legislation and implementation in South Africa.

\section{Results and discussion}

There have been strides taken by the South African government towards the development of renewable energy in the past 20 years, especially with wind and solar deployment. For example, in 2013, solar energy did not feature in South Africa's energy mix, however, in 2016 it contributed to $2151 \mathrm{GWh}$ to the national grid. Wind power produced $18 \mathrm{GWh}$ of electricity in 2013 and $2126 \mathrm{GWh}$ in 2016 [4]. The biggest barriers to reducing the dependency on coal in South Africa are the costs, the rate at how quickly low-carbon energy options can be established on a nationwide scale to meet the country's baseload needs, and the impact on the employment in the fossil fuel industry [9]. In 2019, there were 92230 people employed in the coal industry in South Africa (86647 in 2018), representing approximately $19 \%$ of total employment in the mining sector. The country however has only created 31207 jobs in the renewable energy sector instead of the projected 165688 jobs because the country imported majority of the components used in solar PV and solar concentrated power (CSP) technologies. This reiterates the call for a "just transition plan" towards clean energy being a social and economic alternative [10].

Nonetheless, with the challenges mentioned, there are new national policy documents that are steering the country towards a lower-carbon energy sector, by promoting the increase of renewable energy generation and consumption [11]. The legal mandate to increase the generation and consumption of renewable energy in South Africa originated in 1998 [12]. These are key energy policies and legislations that are shaping the adoption of renewable energy in South Africa (Table 1). 
Key energy policies and legislations in South Africa

Table 1

\begin{tabular}{|c|l|ll|}
\hline Year & \multicolumn{1}{|c|}{ Legislation/Policy } & \multicolumn{1}{c|}{ Target/Objective } \\
\hline 1998 & $\begin{array}{l}\text { White Paper on the Energy } \\
\text { Policy }\end{array}$ & $\begin{array}{l}\bullet \\
\text { An equitable level of national resources must } \\
\text { be invested in renewable technologies (para } \\
7.7) .\end{array}$ \\
\hline $2003 / 04$ & $\begin{array}{l}\text { White Paper on Renewable } \\
\text { Energy }\end{array}$ & $\begin{array}{l}\text { Set the renewable energy target at 10000 GWh } \\
(4 \%) \text { of annual energy generation by 2013. }\end{array}$ \\
\hline 2008 & National Energy Act & $\bullet \begin{array}{l}\text { Ensure that diverse energy resources are } \\
\text { available in sustainable quantities and at } \\
\text { affordable prices in South Africa. }\end{array}$ \\
\hline $2010 / 11$ & $\begin{array}{l}\text { Integrated Resource Plan } \\
\text { (IRP 1) }\end{array}$ & $\begin{array}{l}\text { Targeting 7200MW (16\%) renewable energy } \\
\text { by 2030. } \\
\text { Target of 21,5 GW of new installed renewable } \\
\text { energy generation capacity by 2030, } \\
\text { comprising 9200 MW of wind capacity, 8400 } \\
\text { MW of solar PV capacity, 1200 MW of solar } \\
\text { CSP capacity. }\end{array}$ \\
\hline 2019 & $\begin{array}{l}\text { Adoption of the revised } \\
\text { Integrated Resource Plan } \\
\text { (IRP2019) }\end{array}$ & $\begin{array}{l}\text { Coal contribution to reduce to 58.8\% in 2030, } \\
\text { with renewables rising to 24.7\%. }\end{array}$ \\
\hline
\end{tabular}

The basis of these policies is the promotion of renewable energy while guaranteeing environmental protection. South Africa has adopted renewable energy because of their international commitments to the Copenhagen Accord, UN Sustainable Development Goals and the African Union Agenda 2063 goals towards mitigating climate change and reducing environmental degradation [13]. In section 2 of the National Energy Act 34 of 2008, it strongly advocates for "formulation of an integrated and sustainable energy plan that focuses on issues such as the security of supply; economically available energy sources; affordability; universally accessible, free basic electricity; social equity; employment; the environment; international commitments; consumer protection; and the contribution of the energy supply to socioeconomic development" (Section 6(2) [12]. However, these policies have shortcomings, they advocate for an integrated approach to energy planning and regulation, but do not provide explicit methods to help align the current energy sectors with the distribution and generation of energy.

\section{Institutional fragmentation}

As mentioned above, institutional fragmentation is a barrier that hinders the country from reaching its renewable energy potential that is not constrained by regulatory red-tape and politically wellconnected interest groups in the coal and nuclear sectors [8]. This is a result of various governmental departments explicitly and inexplicitly influencing regulations. Furthermore, developing energy and environmental legislations has always occurred independently because these two sectors have been viewed as institutional silos. This leads to fragmentated planning, as well as the absence of integrative planning when drafting and implementing renewable energy legislation that mirrors environmental law principals. It was only recently that the Department of Environmental Affairs and the Department of Energy developed a common objective that promoted the sustainable use of natural resources, including those resources that would be harnessed during the generation of renewable energy [7]. South Africa needs to reform public policy engagements around the discussions and implementation of environmental and energy issues [14].

\section{Policy and legislation analysis}

The analysis of The Integrated Resource Plan (IRP, 2010-2030) allowed us to highlight the shortcomings of the plan. Firstly, the IRP was first released in 2010 and was to be revised and updated every two years, but the proposed drafts for 2013 and 2016 were not adopted until 2019 and this creates uncertainty towards the government's commitment to diversifying the energy mix [15]. The South African government had set ambitious long-term targets in 2003, aiming at $15 \%$ renewable electricity 
by 2020, unfortunately the abundant coal reserves, overdependence on fossil fuels as cost-effective source of power generation and restrictive policy barriers resulted in only $7 \%$ renewable electricity in 2020 [16]. Additionally, in the White Paper on Renewable Energy of 2003, the renewable energy target was set at $10000 \mathrm{GWh}(4 \%)$ of annual energy generation by 2013; this target was not reached due to poor setting of policies and implementation that discouraged potential investors towards investing in the White Paper deal [1]. We noted that the plan has a narrow focus that prioritises socio-economic and political challenges, although tackling these is important, the IRP should refocus on the impact the electricity sector can play in achieving economic, social, and environmental policy developments. Secondly, the IRP has short-sighted medium-term emphasis on coal capital and labour, instead of more significant national policy obligations. The IRP cites the absence of a "just transition plan", however, this only justifies the continuous use of coal.

The IRP forecasts the contribution of renewables to increase to $24.7 \%$ by 2030 from $11 \%$ [15]. Fig. 1 illustrates the installed capacity energy targets as outlined in IRP2019. Capacity being "the maximum net generating capacity of power plants and other installations that use renewable energy sources to produce electricity" [17]. It is evident that South Africa has better potential to address its energy challenges through using solar and wind energy. However, with the forecasted contributions, the build limits put restrictions on how much new renewable energy can come online every year. These restrictions limit new capacity to $1000 \mathrm{MW} \cdot \mathrm{y}^{-1}$ for solar PV, and $1600 \mathrm{MW} \cdot \mathrm{y}^{-1}$ for wind power [18]. To reach the target of increasing renewable energy by $41 \%$ (Fig 1) and reducing dependency on fossil fuels, $17742 \mathrm{MW}$ of wind, $8288 \mathrm{MW}$ of solar PV, $4600 \mathrm{MW}$ of hydropower, and $600 \mathrm{MW}$ of CSP must be installed by 2030 [19]. Even with these targets, the infancy of some renewable technologies and the high cost associated with building new energy developments is an obstacle to reaching these targets, as these new sources must compete with an established fossil fuel industry. The fossil fuel industry can only be challenged through appropriate strategies to mitigate any shocks during the transition to renewable energy [20].

INSTALLED CAPACITY 2018

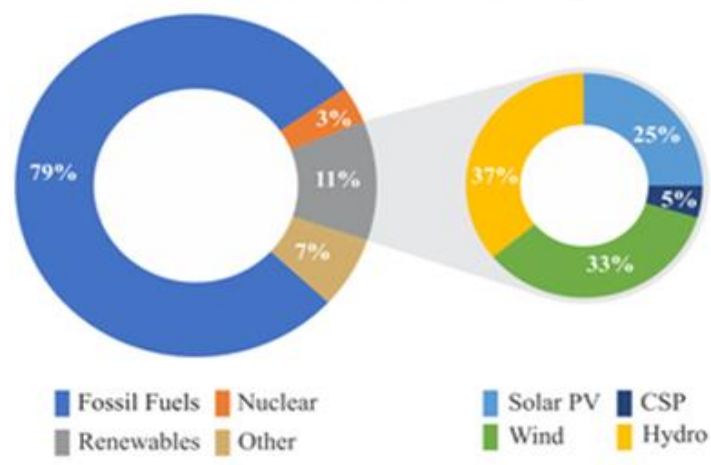

-Fossil Fuels includes Coal \& Natural Gas / Diesel. -Other includes Cogeneration. Biomass, \& Landfill.
IRP TARGET BY 2030

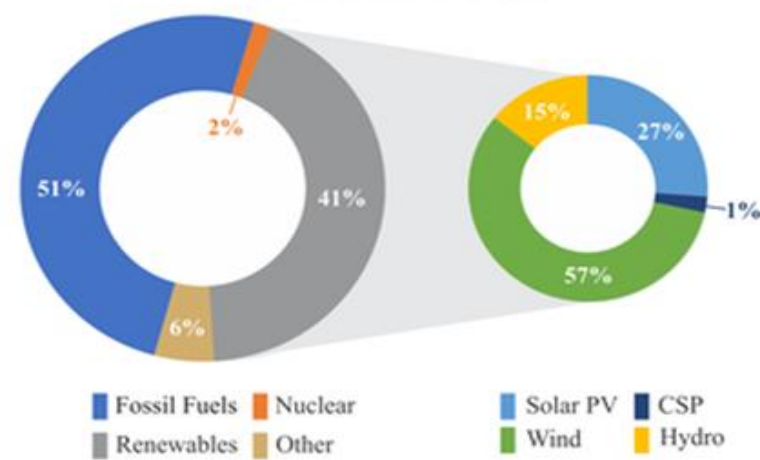

•Others includes Storage (Pumned Storagei.

Fig. 1. South Africa's 2019 IRP Renewable Energy Targets [19]

The IRP2010 detailed capacity distributions for electricity generated from renewable sources and it is with these said allocations that former Minister of Energy released section 34 determinations for renewable energy [1]. These consisted of the following technologies: solar PV, wind, solar CSP, landfill gas, biomass, small hydro technologies ( $\leq 40 \mathrm{MW})$ and small projects $(\leq 5 \mathrm{MW})$. The Renewable Energy Independent Power Producer Programme (REIPPP) was introduced in 2011 as a procurement programme initiative. By 2019, under this initiative, there were 92 projects and $6327 \mathrm{MW}$ of renewable energy technology [8]. The two most dominant renewable energy technologies in IRP2019 were wind and solar PV. The IRP is planning to increase the allocation for wind annually starting in 2022 to 2030 by $1600 \mathrm{MW}$ up to $14400 \mathrm{MW}$. While solar PV allocation will be increased by $1000 \mathrm{MW}$ annually until 2030, to reach $6000 \mathrm{MW}$ [21]. The current allocations and capacity gained from the 92 projects is detailed in the Table 2 below. It is also evident that solar PV (ground or rooftop) and wind have better potential than biomass, landfill, and hydropower. 
Current allocations and capacity gained from REIPPP energy projects

Table 2

\begin{tabular}{|l|c|c|}
\hline \multicolumn{1}{|c|}{ Energy technology } & Project No. & Capacity (MW) \\
\hline Onshore wind & 34 & 3357 \\
\hline Solar PV & 45 & 2292 \\
\hline Solar CSP & 7 & 600 \\
\hline Landfill gas & 1 & 18 \\
\hline Biomass & 2 & 42 \\
\hline Small hydro & 3 & 19 \\
\hline
\end{tabular}

Fig. 2 below illustrates how some African nations grew in renewable capacity in comparison to South Africa. South Africa has increased its installed capacity from 993 MW in 2010 to 6167 MW in 2019 as result of its policy and regulations. However, the renewable energy capacity of South Africa experienced steady growth in its early development between 2012 and 2016, nevertheless renewable energy growth stagnated over last few years (2017 to 2019) [17]. Other African countries including Egypt, Morocco, and Kenya experienced similar stagnation largely due to restrictive policies and to gaps in auction programs. At continental level, Morocco is at the forefront of development and generation of renewable resources in Africa, while South Africa is the leader in renewable energy capacity. While broader structural and political issues exist, South Africa needs to invest in its energy sector to increase not only the capacity, but also energy access in the country. In 2017, 85\% of South Africans had access to power, thus reforming the build limit policy would result in $95 \%$ of people having access to grid or off grid electricity in 2030(22).

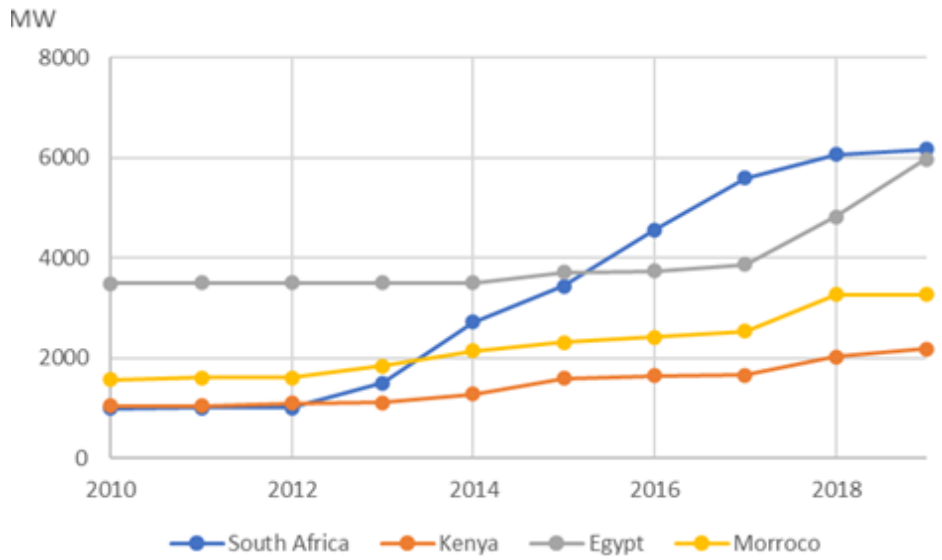

Fig. 2. African nations renewable capacity (2010-2019); Source: IRENA,2020

\section{Global perspective}

In 2019, Compare the Market conducted a study that analysed the energy usage of 21 countries. The study focused on how these countries invested in climate-friendly energy resources (wind, solar, hydropower and bioenergy). It ranked them; South Africa is ranked 15th with a comparatively low renewable usage level of 2.25\% [14]. Germany ranked first (12.74\%) and the main reasons for their renewable energy use being high is the reduced dependency on coal, and the large investments committed by the government to meet the objective of the Paris Agreement [22]. The UK (11.95\%) ranked second, and the USA (4.32\%) ranked $14^{\text {th }}$. Although South Africa ranks $15^{\text {th }}$, with more innovation, independent power producers, reduced coal dependency, the government would reach several of its set policy targets.

\section{Future of renewable energy generation}

The main factor driving support for renewables is the declining price trend, especially with solar PV and wind; the relatively short period with which these projects can be developed, and most important, is reducing the country's carbon footprint [23]. At national level, the approval of the revised IRP2019 should be considered a step forward for South Africa, which has huge energy investment potential. South Africa is conveying a message that its institutions are working together towards the set goals and 
objectives, and are ready to work alongside the private sector to achieve a common development vision [18]. While there are progressive policy developments that have been fundamental towards procurement and development of utility-scale renewable energy generation, the existing highly regulated legal framework creates barrier for developing captive renewable energy projects (the ability for an individual developer to try and sell its energy to a private offtaker) [9]. Our research highlights the importance of establishing an enabling environment that will create a level playing field for renewable energy technologies to compete with alternative technologies and for governments to commit to promoting renewable resources and creating new employment within this sector. This has been moderately achieved in South Africa with the establishment of power purchase agreements, equal access to the grid, allowing the renewable energy sector to grow, funding for research and development [24].

\section{Conclusions}

In conclusion, it is evident that the South African energy policy and legal regulations are highly complicated and dynamic. However, the same energy landscape can be described as rigid and embedded in a national system, where energy and infrastructure provision appear to be static and largely inadequate. While IRP 2019 promotes a diversified energy mix, which includes coal, renewables, and nuclear, the country will still largely depend on coal. Our recommendations to overcome these barriers include the following.

1. Establishing a single regulatory institution that will ensure that energy legislation equally incorporates environmental law into renewable energy law to address fragmentation.

2. Reducing dependency on coal as the main energy supply from over $80 \%$ to $51 \%$ in 2030 , which will result in a reduction of health complications due to air pollution.

3. Reforming the build limit using a just transition strategy to increase the contribution of renewable energy into the grid from $7 \%$ in 2019 to $24.7 \%$ in 2030 .

4. Updating and adopting the IRP every two years as mandated to better monitor progress of existing projects.

5. Restructuring and reforming Eskom to increase its energy availability factor from $65 \%$, so that $95 \%$ of people are having access to grid or off grid electricity in 2030.

6. Retire old coal plants to decommission 10500 MW by 2030-2040 and build new renewable energy capacity to reach $70-80 \%$ renewables by 2050 .

\section{References:}

[1] South Africa Energy Situation - energypedia.info [online] [15.03.2021] Available at: https://energypedia.info/wiki/South_Africa_Energy_Situation\#Key_Problems_of_the_Energy_Se ctor

[2] Covington, Fontana B.L.-L., Wing S. Renewable energy policy and regulation in South Africa |Lexology [online] [13.03.2021] Available at: https://www.lexology.com/library/detail.aspx?g = b1c50016-6753-4406-9687-2cf439fafb55

[3] Chirambo D. Insights into Social and Institutional Innovations for Enhancing Energy Decentralisation and Climate Change Mitigation in Developing Countries. Journal of Sustainable Development Studies. 2019 Feb 20;12(1).

[4] Africa SS. Electricity: Coal use inches lower as solar, wind and diesel rise / Statistics South Africa [online] [07.05.2021] Available at: http://www.statssa.gov.za/?p = 11292

[5] Jain S., Jain P.K. The rise of Renewable Energy implementation in South Africa. Energy Procedia. 2017 Dec 1;143, pp. 721-726.

[6] Eskom: Here's how electricity prices have increased since 1970. The South African. 2019 [online] [08.05.2021] Available at: https://www.thesouthafrican.com/news/eskom-electricityprices-for-april-from-1970/

[7] Murombo T. Legal and policy barriers to renewable and sustainable energy sources in South Africa. The Journal of World Energy Law \& Business. 2016 Apr 1;9(2), pp. 142-165.

[8] Mauger R., Barnard M. Addressing fragmentation in the South African renewable energy governance effort - lessons to be learnt from France. Journal of Energy in Southern Africa. 2018 Feb;29(1), pp. 1-10. 
[9] Shakouri B., Yazdi S.K. Causality between renewable energy, energy consumption, and economic growth. Energy Sources, Part B: Economics, Planning, and Policy. 2017 Sep 2;12(9), pp. 838-845.

[10] Coal - Minerals Council South Africa [online] [07.05.2021] Available at: https://www.mineralscouncil.org.za/sa-mining/coal

[11] Fraser T. Does social capital boost or block renewable energy siting? South African solar politics in comparison. Energy Research \& Social Science. 2021 Jan 1;71:101845.

[12] National Energy Act 34 of 2008 | South African Government [online] [29.03.2021] Available at: https://www.gov.za/documents/national-energy-act\#

[13] Africa 2030 Roadmap for a Renewable Energy Future.pdf [online] [08.05.2021] Available at: https://www.irena.org/-

/media/Files/IRENA/Agency/Publication/2015/IRENA_Africa_2030_REmap_2015_low-res.pdf

[14] Bayer B., Schäuble D., Ferrari M. International experiences with tender procedures for renewable energy-A comparison of current developments in Brazil, France, Italy and South Africa. Renewable and Sustainable Energy Reviews. 2018 Nov 1;95, pp. 305-327.

[15] IChemE. South Africa unveils 2030 power plan [online] [29.03.2021] Available at: https://www.thechemicalengineer.com/news/south-africa-unveils-2030-power-plan/

[16] Energy-2020-promotional-guidelines.pdf [online] [29.03.2021] Available at: https://www.nortonrosefulbright.com/-/media/files/nrf/nrfweb/knowledge-pdfs/energy-2020promotional-guidelines.pdf?la $=$ en-za\&revision $=$

[17] Africa 2030: Roadmap for a Renewable Energy Future. :72.

[18] 2019-South-African-Energy-Sector-Report.pdf [online] [15.03.2021] Available at: http://www.energy.gov.za/files/media/explained/2019-South-African-Energy-Sector-Report.pdf

[19] South Africa's 2019 IRP Renewable Energy Targets — Climate Policy Lab [online] [09.05.2021] Available at: https://www.climatepolicylab.org/communityvoices/2020/5/13/south-africas-2019irp-renewable-energy-targets

[20] Aliyu A.K., Modu B., Tan C.W. A review of renewable energy development in Africa: A focus in South Africa, Egypt and Nigeria. Renewable and Sustainable Energy Reviews. 2018 Jan 1;81, pp. 2502-2518.

[21] Nakumuryango A, Inglesi-Lotz R. South Africa's performance on renewable energy and its relative position against the OECD countries and the rest of Africa. Renewable and Sustainable Energy Reviews. 2016 Apr 1;56, pp. 999-1007.

[22] Africa ESI. Top ten global countries with the highest proportion of renewables ESI-Africa.com. 2021 [online] [26.03.2021] Available at: https://www.esi-africa.com/industry-sectors/renewableenergy/top-ten-global-countries-with-the-highest-proportion-of-renewables/

[23] Lucas H., Pinnington S., Cabeza L.F. Education and training gaps in the renewable energy sector. Solar Energy. 2018 Oct 1;173, pp. 449-455.

[24] Thopil M.S., Bansal R.C., Zhang L., Sharma G. A review of grid connected distributed generation using renewable energy sources in South Africa. Energy strategy reviews. 2018 Aug 1;21, pp. 8897. 